\title{
Note
}

\section{Food and feeding habits of the narrow barred Spanish mackerel Scomberomorus commerson (Lacepede, 1800) off Karnataka, south-west coast of India}

\author{
K. M. RAJESH, P. ROHIT, S. THOMAS, V. SUPRABHA, G. D. NATARAJA \\ AND G. SAMPATHKUMAR \\ Mangalore Research Centre of ICAR-Central Marine Fisheries Research Institute, P. B. No. 244, Hoige Bazar \\ Mangalore - 575 001, Karnataka, India \\ e-mail: rajeshmkm3@rediffmail.com
}

\begin{abstract}
Scomberomorus commerson were collected on weekly basis during January 2012 to December 2014 at Mangalore Fishing Harbour. Stomach of 214 narrow barred Spanish mackerel measuring from 48 to $105 \mathrm{~cm}$ fork length (FL) for males and 45.5 to $115 \mathrm{~cm}$ FL for females were analysed to study their feeding habits. Fish with empty stomach were prevalent in almost all the months. Prey mainly comprised of fishes and crustaceans, with the fish component forming $99.9 \%$. The index of relative importance (IRI) showed that the dominant prey were semi-digested fish remains (44.6\%) of Sardinella longiceps (30.1\%), Decapterus sp. (18.7\%), whitebaits (2.5\%), Rastrelliger kanagurta (1.5\%) and Epinephelus spp. (1.1\%), while Saurida sp. $(0.7 \%)$, Megalaspis cordyla (0.5\%), Scombroides sp. (0.2\%) and shrimps $(0.1 \%)$ were found occasionally in the gut. Index of stomach fullness (SFI) was 0.11 in August and 0.65 in January. Generally, SFI was higher during September to January and lower during February to August. The empty stomach ratio (ESR) ranged from 33.3\% (August) to 92.3\% (April).
\end{abstract}

Keywords: Feeding, IRI, Karnataka, Narrow barred Spanish mackerel, Prey, Scomberomorus commerson

The species belonging to the family Scombridae and genera Scomberomorus and Acanthocybium are popularly known as seerfish or Spanish mackerel. The seerfish form an important and valuable component of marine fishery resource of India. The group mainly included the narrow barred Spanish mackerel Scomberomorous commerson (Lacepede, 1800), Indo-pacific king mackerel S. guttatus, the streaked seer fish $S$. lineolatus and wahoo Acanthocybium solandri. Of these, S. commerson and $S$. guttatus are landed in abundance, while $S$. lineolatus and $A$. solandri are landed in insignificant quantities. The king seer $S$. commerson, is a carnivorous epipelagic fish distributed all through the coastal tropical waters of Indo-Pacific to the South-east Asia, in the north China and Japan and South to Australia (Randall, 1995). It migrates up to 1000 nautical miles along shore (Mc Pherson, 1989) and grows up to $240 \mathrm{~cm}$ and weighs up to $70 \mathrm{~kg}$ (Mc Pherson, 1992).

The king seer contributed $75.8 \%$ of total seerfish catch of India in the year 2012 (CMFRI, 2013). It's catch in India for the last decade has registered a high fluctuation with minimum of 27,226 tin 2001 and maximum of 42,607 t during 2012. However, in Karnataka, the catch steadily increased from 2,209 $\mathrm{t}$ in 2001 to 7,664 $\mathrm{t}$ in 2011 (Fig. 1). It is being caught by different types of craft and gear combinations. The large meshed gillnets $(65-170 \mathrm{~mm})$ contributed more than

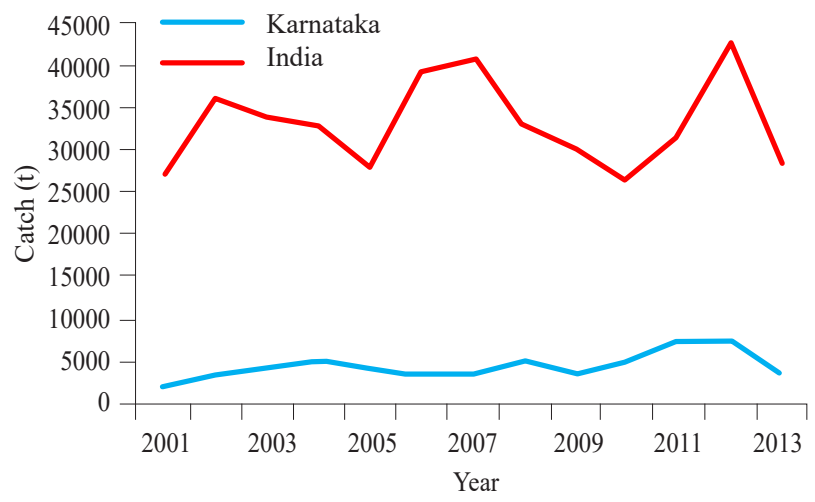

Fig. 1. Landings of narrow barred Spanish mackerel in India and Karnataka during 2001-2013

$65 \%$ of the catch followed by trawls $(20 \%)$ and hook lines $(5 \%)$. Seines, trolls and other indigenous gears contributed to the rest of the catch. Food and feeding habit is an important factor in governing growth, condition, fecundity, migration and breeding pattern of fish (Rao, 1978). Stomach content analysis has been reported as a common method for assessing the diet of fish, describing food chain and webs shared by different species (Rice, 1988) and further providing information about the fish habitats. There are a few published information on food and feeding pattern of narrow barred 
Spanish mackerel (Blaber et al., 1990; Bakhoum, 2007). Information on food and feeding of $S$. commerson is scarce in Indian waters. Hence, this work was taken up to study the feeding behaviour of $S$. commerson exploited off Karnataka.

Narrow barred Spanish mackerel caught from the Arabian Sea, off the south-west coast of India between lat $12.87^{\circ}-15.55^{\circ}$ and long. $73.38^{\circ}-75.27^{\circ}$ was used for the study (Fig. 2). Weekly collections were made from gillnets operated from Mangalore Fishing Harbour. In all, the feeding pattern of 214 fishes collected between January 2013 and December 2014 were studied.

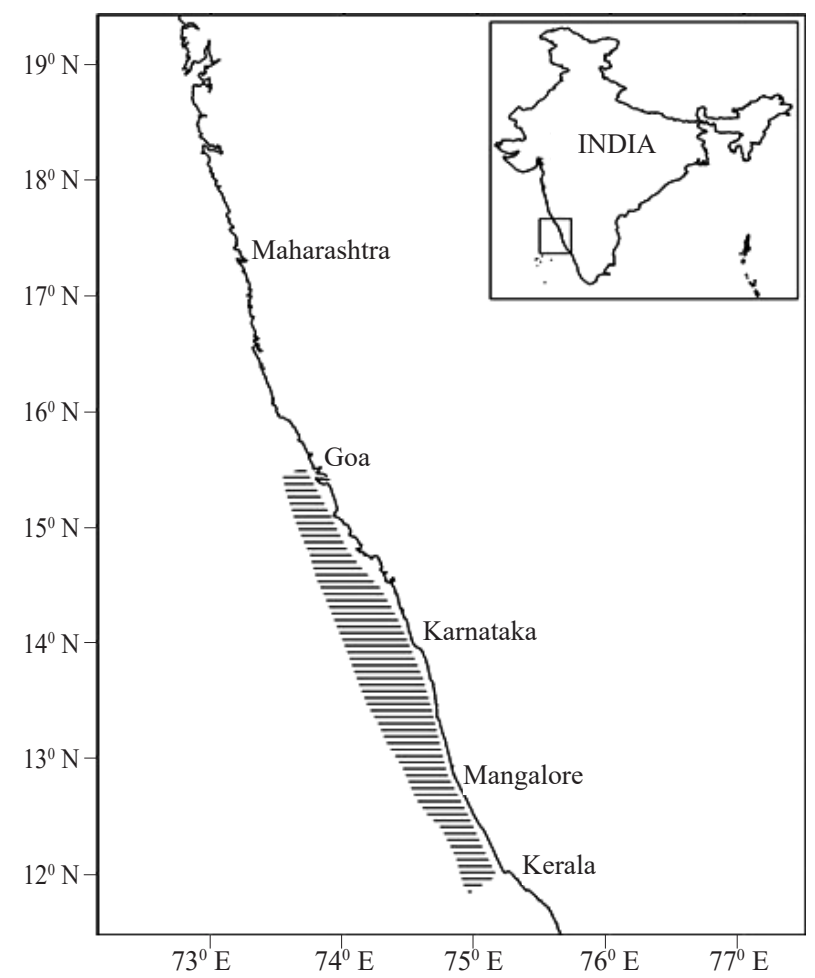

Fig. 2. Map showing operational area of gillnets off Arabian Sea

Samples of narrow barred Spanish mackerel collected at the landing centre were measured for their fork length, FL $(\mathrm{cm})$ and wet weight $(\mathrm{g})$. Stomach was carefully dissected and kept aside for further detailed analysis. Different stages of gonadal maturity and sex were also documented for each fish. The stomach was cut open and the weight of the entire content taken. The food items were sorted out and the recognisable prey were listed to the lowest taxon possible. The number of each food item was counted and weight recorded to the nearest $0.01 \mathrm{~g}$. The partially digested food items were classified as semi-digested fish remains.

The feeding intensity and the empty stomach ratio (ESR) were considered to determine the feeding periodicity. The stomach fullness index (SFI) was used to measure degree of feeding intensity. The SFI was calculated as (Chiou et al., 2006):

$$
\mathrm{SFI}=\frac{\text { Weight of the stomach content }}{\text { (Body weight }- \text { weight of the stomach content) }} \times 100
$$

The ESR was calculated as the percentage of the number of specimens with an empty stomach, of the total number of specimens examined.

The relative importance of each prey item and their seasonal variations were analysed (Pinkas et al., 1971) on the basis of three indices: (i) percentage of wet weight of each food item to the total wet weight of all food items identified $(\% \mathrm{~W})$; (ii) percentage of the number of each food item to the total number of all food items identified $(\% \mathrm{~N})$; and frequency of occurrence of each food item in the total number of stomachs examined $(\% \mathrm{~F})$. The index of relative importance (IRI) was calculated as follows: $I R I=(\% \mathrm{~N}+\% \mathrm{~W}) \times \% \mathrm{~F}$.

In all, 214 fishes were collected and analysed, of which $113(52.8 \%)$ had empty stomach. The fork length (FL) of S. commerson samples collected ranged from 46 to $115 \mathrm{~cm}$. Prey mainly comprised fishes and crustaceans with the fish component forming $99.9 \%$ of the diet (Table 1). In the present study, 10 prey items were recorded in the gut of S. commerson. Devaraj (1998) also reported finfishes to be the most abundant prey item in the stomach of king seer in the seas around the Indian Peninsula. However, Devaraj (1998) recorded 25 prey items in the gut of seerfish which is comparatively higher than the prey recorded in the present study. This could be due to the drastic change in fishing pattern as the exploitation of seerfish by the gillnetters was taking place only at depths of 50-60 m during 90's compared to the present exploitation of depths up to 150-200 $\mathrm{m}$. The availability of prey items are lesser in higher depths compared to shallow coastal areas. Studies conducted at Soloman Island (Blaber et al., 1990) and Egyptian Mediterranean coast (Bakhoum, 2007) showed finfish and shrimp as the main constituent of the diet of S. commerson. However, Johnson and Tamatamah (2013) observed wide varieties of preys such as fish, crustaceans, cephalopods and gastropods in the stomach of $S$. commerson off Dar-es-Salaam, Tanzania. The adults of three Scomberomorus species ( $S$. commerson, S. guttatus and S. lineolatus) feeds on small pelagic fishes but occasionally feeds on squids and penaeid shrimps (Mc Pherson, 1987).

Semi-digested fish remains, Sardinella longiceps, Decapterus russelli, whitebaits, $R$. kanagurta and Epinephelus spp. were the major food items identified based on the IRI values. Other recognisable prey items (Saurida sp., Megalaspis cordyla and Scombroides sp.) were found in very small numbers. Shrimps were found intermittently in the gut in insignificant quantity $(\% \mathrm{IRI}=0.07)$. The most frequent 
Table 1. Index of relative importance (IRI) of each food item in the diet of S. commerson

\begin{tabular}{llllll}
\hline Food item & $\% \mathrm{~F}$ & $\% \mathrm{~N}$ & $\% \mathrm{~W}$ & $\mathrm{IRI}$ & \%IRI \\
\hline Semi-digested fish remains & 39.60 & 31.95 & 10.76 & 1582.50 & 44.62 \\
S. longiceps & 12.00 & 23.61 & 27.07 & 1066.87 & 30.08 \\
D. russelli & 10.00 & 13.89 & 23.97 & 664.20 & 18.73 \\
White baits & 3.51 & 12.50 & 13.11 & 89.84 & 2.53 \\
R. kanagurta & 3.51 & 4.17 & 11.08 & 53.49 & 1.51 \\
Epinephelus spp. & 3.51 & 5.56 & 5.53 & 38.91 & 1.1 \\
Saurida spp. & 3.51 & 2.78 & 4.22 & 24.55 & 0.69 \\
M. cordyla & 3.51 & 2.78 & 2.23 & 17.58 & 0.5 \\
Scombroides spp. & 1.75 & 1.39 & 1.94 & 5.84 & 0.16 \\
Shrimps & 1.75 & 1.39 & 0.1 & 2.61 & 0.07 \\
\hline
\end{tabular}

food item in the stomach of $S$. commerson was semi-digested fish remains followed by $S$. longiceps and $D$. russelli. The most important food items by weight were $S$. longiceps, $D$. russelli, whitebaits and R. kanagurta while semi-digested fish remains of $S$. longiceps, D. russelli and anchovies were the most important food in terms of number (Table 1).

Of all the identified prey items, $S$. longiceps was the predominant prey in the gut of $S$. commerson with the highest percent weight $(\% \mathrm{~W})$, percent frequency $(\% \mathrm{~F})$, percent number $(\% \mathrm{~N})$ and percent IRI (\%IRI). Incidentally, $S$. longiceps was the dominant component of the marine fish catch of Karnataka and contributed to $22.5 \%$ of the total marine fish landings during 2013 (CMFRI, 2014). Other significant items observed in the diet included Decapterus spp., whitebaits, $R$. kanagurta and Epinephelus spp. All these fishes formed a major component of the commercial fishery of the region (CMFRI, 2014). Similar feeding pattern with Decapterus spp., as dominant food item followed by $R$. kanagurta, $S$. longiceps, Epinephelus sp., Saurida sp., Chorinemus sp., M. cordyla and whitebaits has been reported in S. commerson from Indian waters (Rohit and Abdussamad, 2013). However, Bakhoum (2007) has observed Engraulis encrasicolus, Sardinella aurita, Sardina pilchardus and shrimps as dominant diet components of S. commerson from Egyptian Mediterranean coast.

A seasonal change in water temperature and fish food organisms corresponds to the change in feeding activity of fish (Sakamoto, 1982). Seasonal variation in feeding pattern indicated that the maximum amount of food was consumed from September to January (SFI, 0.4-0.65) and lowest during February to August (SFI, 0.11-0.28) (Fig. 3). SFI varied between 0.11 in August and 0.65 in January. Generally, greater SFI was observed during September to January and lesser during February to August. Johnson and Tamatamah (2013) noticed highest percentage of stomach fullness during May and June in S. commerson caught off Dar es Salaam, Tanzania, while Bakhoum (2007) recorded highest amount of food in the gut of $S$. commerson from summer to autumn in Egyptian Mediterranean coast.

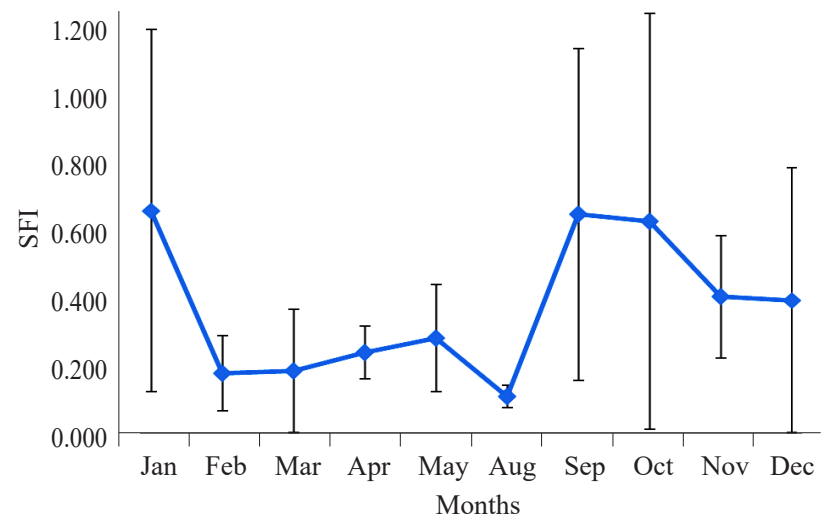

Fig. 3. Stomach fullness index (SFI) of S. commerson

Empty stomach ratio (ESR) ranged from 33.3\% (August) to $92.3 \%$ (April). Generally, ESR values were higher during April to May and lower during August and November to January (Fig. 4). The high percentage of empty stomachs noticed in the present study is characteristic of fishes which prey upon small teleosts as described by Juanes and Conover (1994). Seasonal variation in the diet composition of king seer was not prevalent in the present study. This could be due to the abundance of favourite prey item during all the seasons in the study area.

The present study indicated that $S$. commerson is a carnivore and mainly feeds on small pelagic fishes which

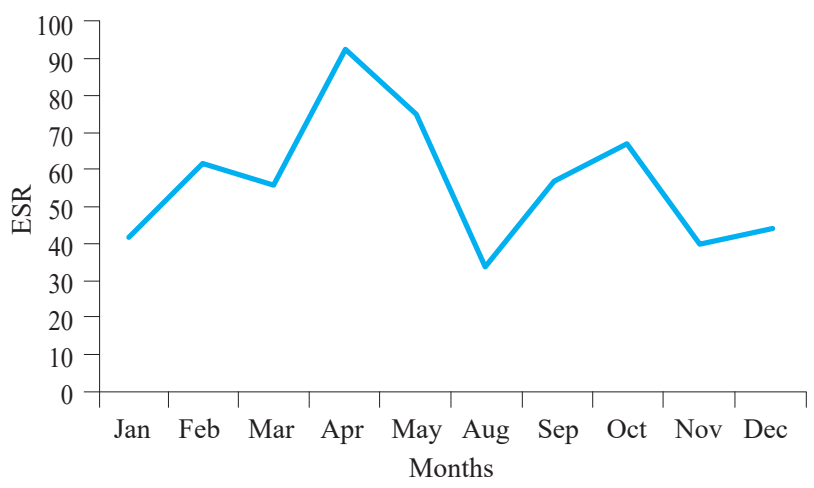

Fig. 4. Empty stomach ratio (ESR) of S. commerson 
include S. longiceps, whitebaits, R. kangurta, Epinephelus spp. Saurida spp. and M. cordyla. The study has indicated seasonal variation in feeding activity. This information on feeding habits and ecological interactions of narrow barred spanish mackerel is important particularly for the management and conservation of the fishery resources and marine ecosystem.

\section{Acknowledgements}

Authors would like to express their gratitude to the Director, ICAR-CMFRI, Kochi for facilitating this work as well as for the constant support and encouragement.

\section{References}

Bakhoum, S. A. 2007. Diet overlap of immigrant narrow-barred Spanish mackerel Scomberomorus commerson (Lac. 1802), the large head hairtail ribbonfish Trichiurus lepturus (L., 1758) in the Egyptian Mediterranean coast. Anim. Biodivers. Conserv., 30: 147-160.

Blaber, S. J. M., Milton, D. A., Rawlinson, N. J. F., Tiroba, G. and Nicholas, P. V. 1990. Diets of lagoon fishes of the Solomon islands: predators of tuna baitfish and trophic effects of bait fishing on the subsistence fishery. Fish. Res., 8: 263-286.

Chiou, W., Chen, C., Wang, C. and Chen, C. 2006. Food and feeding habits of ribbonfish Trichiurus lepturus in coastal waters of south-western Taiwan. Fish. Sci., 72: 373-381.

CMFRI 2013. Annual report 2012-13. Central Marine Fisheries Research Institute, Kochi, $200 \mathrm{pp}$.

CMFRI 2014. Annual report 2013-14. Central Marine Fisheries Research Institute, Kochi, 272 pp.

Devraj, M. 1998. Food and feeding habits of the king seer, Scomberomorous commerson (Lacepede), in the seas around the Indian Peninsula. J. Mar. Biol. Ass. India, 40: 69-90.

Johnson, M. G. and Tamatamah, A. R. 2013. Fishery and feeding habits of Kawakawa (Euthynnus affinis Cantor 1849) and narrow barred Spanish mackerel (Scomberomorus commerson Lacepede 1800) in the Coastal waters of Dar es Salaam
Tanzania. Third Working Party on Neritic Tunas, Bali, Indonesia, 2-5 July 2013, IOTC-2013-WPNT03-21.

Juanes, F. and Conover, D. O. 1994. Rapid growth, high feeding rates and early piscivory in young-of-the-year blue fish (Pomatomus saltatrix). Can. J. Fish. Aquat. Sci., 51: 1752-1761.

McPherson, G. R. 1987. Food of narrow barred Spanish mackerel in north Queensland waters and their relevance to the commercial troll fishery. Queensl. J. Agric. Anim. Sci., 44: 69-73.

McPherson, G. R. 1989. North-eastern Australian mackerel (Scomberomorus) fishery. In: Chavez, E. A. (Ed.), Proceedings of the Workshop Australia-Mexicoon Marine Science, Quintana Roo, Mexico, 6-17 July 1989, 348 pp.

McPherson, G. R. 1992. Age and growth of the narrow barred Spanish mackerel (Scomberomorus commerson Lacepede, 1800) in north-eastern Queensland waters. Aust. J. Mar. Fresh. Res., 43(5): 1269-1282.

Pinkas, L., Oliphant, M. S. and Iverson, L. K. 1971. Food habits of albacare, bluefin tuna and bonito in California waters. State of California the Resource Agency Department of Fish and Game. Fish. Bull., 152: 1-105.

Randall, J. E. 1995. Coastal fishes of Oman. University of Hawaii Press, Honolulu, Hawaii, 439 pp.

Rao, K. S. 1978. Size composition of catch and growth of Scomberomorus guttatus off Waltair. In: Abstract of papers, Summer School on Fishery Biology, College of Fisheries, Mangalore, 10-14 April 1978, p.15-16.

Rice, J. C. 1988. Repeated cluster analysis of stomach contents data: Method and application to diet of cod in NAFO division $3 \mathrm{~L}$. Environ. Biol. Fish., 21(4): 263-277.

Rohit, P. and Abdussamad, E. M. 2013. Fishery, biology and population characteristics of the narrow barred Spanish mackerel Scomberomorus commerson exploited in India. Third Working Party on Neritic Tunas, Bali, Indonesia, 2-5 July 2013, IOTC-2013-WPNT03-26.

Sakamoto, T. 1982. Studies on fishery biology of the ribbonfish, Trichiurus lepturus, Linn. in the Kiil60 Bakhoum channel. Wakayama Pref. Fish. Std., 111-115. 